\title{
難治性気胸に対する治療戦略一気管支充填術と50 $\mathrm{cmH}_{2} \mathrm{O}$ 陰圧下に行う胸膜癒着療法の併用一
}

\author{
本間 崇浩，新納 英樹，宮澤 秀樹，能登 啓文
}

\begin{abstract}
要旨
2002年から2006年までに当院に入院し保存的治療法を行った難治性気胸45例（47側）について検討した，治療方針 は胸腔ドレーン挿入後の気漏程度と肺の再膨張に基づき, ドレナージ単独, 胸膜癒着療法, 気管支充填術併用のいず れかに決定した，気管支充填術はシリコン性気管支充填材を用い, 胸膜癒着療法は50 $\mathrm{cmH}_{2} \mathrm{O}$ 陰圧下で積極的に癒着 を図った。胸膜癒着療法群 1 例, 非治療関連の在院死 3 例を除いて, 初回に選択した治療で気漏が停止し退院となっ た。平均入院期間はドレナージ単独群8.4日, 胸膜癒着療法群 23.5 日, 気管支充填術併用群 25.5 日で, 手術を施行せず に初回治療で確実かつ早期の気漏停止が可能であった。気管支充填術併用群では再発を認めず(観察期間23〜81カ月), 当院の治療戦略は安全性が高く, 再発が少ない点で有効な治療方法と考える.
\end{abstract}

索引用語：難治性気胸, 胸膜癒着療法, 気管支充填術 intractable pneumothorax, pleurodesis, bronchial occlusion, endobronchial Watanabe spigot (EWS) endobronchial Miyazawa valve (EMV)

\section{背景}

高齢者や低心肺機能患者における気胸は，緊急性， 重症度の高い症例や入院が長期化する症例が多く，早 期治療，早期退院が目標となる。しかし，このような 症例ほど気漏の遷延や再発が多く, 周術期管理が困難 で合併症も懸念されるために治療法の選択に悩む。手 術よりも保存的に早期治癒が得られ，かつ再発が少な い治療法が望ましい.

これまで保存的治療の中心として行われてきた胸膜 癒着療法は, 初回で確実な治療成績を得ているとは言 い難く，再発例も多い1)。原因として(1)肺の再膨張が 得られなければ癒着が困難である点, (2)大きな気胸腔 や強い気漏が残存する症例では癒着が部分的で不十分 な効果しか得られない点2), (3)投与薬剤により癒着効 果が異なる点，の 3 点が挙げられる。 また癒着療法後

富山県立中央病院 呼吸器外科

原稿受付 2008年 9 月20日

原稿採択 2008年12月10日
の再発症例では, 部分的な癒着から気胸腔が不規則と なり胸腔ドレーン挿入が困難となる場合がある11.

当院では気胸保存的治療の基本方針として肺再膨張 と確実な肺癒着を挙げている。再膨張を妨げる高度な 気漏に対しては，有効性が報告されている気管支充填 材3）を用いて速やかな気漏の減少または停止を図る。 気漏部位を含めた広範囲な癒着を促すためには電動式 持続吸引器を用いて $50 \mathrm{cmH}_{2} \mathrm{O}$ 陰圧下に胸膜癒着療法 を行っている，本稿ではこの治療戦略の方法と成績を 報告する。

\section{対}

難治性気胸は厳密には定義されていないが, 既往疾 患，合併症，高齢により周術期管理が困難な症例，高 度の癒着や肺気腫合併により術後の肺瘦が強く懸念さ れる症例を難治性気胸と捉える。したがって難治性気 胸は積極的に手術を行う対象とはならず，我々はこれ らを「気胸保存的治療群」と命名した，2002年 1 月か ら2006年12月までに自然気胸の診断で入院加療を行っ 


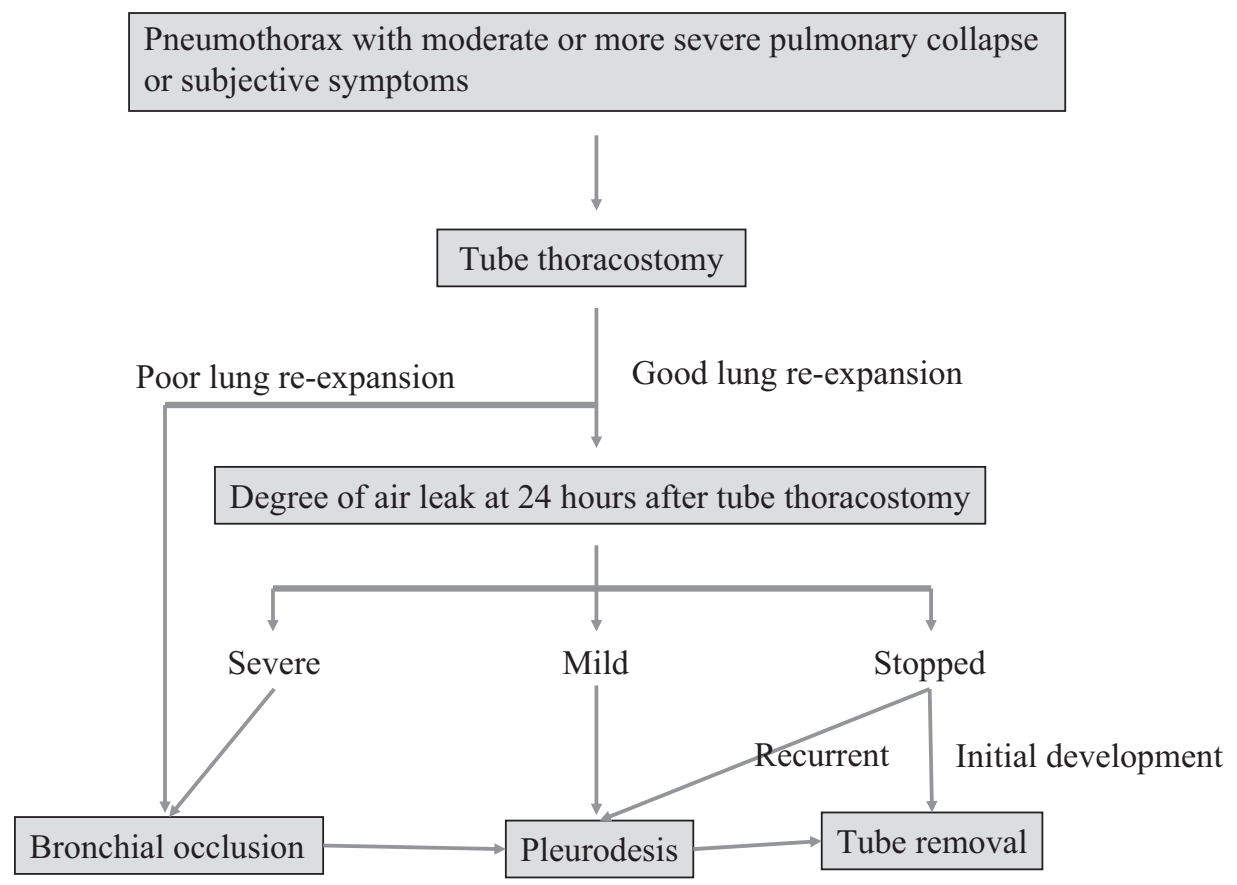

Fig. 1 Algorithm. Management of patients with intractable pneumothorax.

た全252例のうち, 気胸保存的治療群に該当した45例 （47側）を対象とした。本法の実施に際しては当院の 倫理委員会の承諾を得た上で，患者および家族に対し て治療内容を十分に説明し文書同意を得た。

\section{方法}

\section{治療方針}

日本気胸囊胞学会における気胸虚脱程度分類に従い, 自覚症状を有する症例もしくは中等度以上の虚脱症例 に20Fr トロッカー（シングルルーメン）を用いて胸腔 ドレナージを行う。原則ドレナージ後に各種検査を行 い，全身状態や基礎疾患を下に手術療法または保存的 治療を選択する。

保存的治療群は肺再膨張の有無と気漏程度に基づき, 当院の治療アルゴリズム（Fig. 1）に沿って治療法を 選択する，肺再膨張は胸部単純レントゲン写真で判定 する。気漏程度は持続低圧吸引器 $(\mathrm{MS}-007 \mathrm{~K}$ もくは 008，アクアシール D2．ともに泉工医科工業株式会社 製）を用い胸腔ドレナージ24時間後に $-15 \mathrm{cmH}_{2} \mathrm{O}$ 下 で判断する. Severe（呼気吸気ともに持続的な気漏を 認める), Mild (呼気のみ気漏を認める), Stopped（気 漏を認めない）の 3 段階に分類する. 初発の Stopped 症例はドレナージ単独群とする. Mild か再発の
Stopped 症例は胸膜癒着療法群とする. Severe もしく は再膨張不全症例は気管支充填術併用群とする。

\section{胸膜癒着療法}

1. 薬剂：ミノサイクリン $200 \mathrm{mg}$ と OK-432 5 単 位を併用する．前投薬としてペンタゾシン $15 \mathrm{mg}$ を 投与後に, 両薬剤をブピバカイン $2.5 \mathrm{mg}$ と生理食塩 水 $50 \mathrm{ml}$ とともに, トロッカーより胸腔内へ注入する. 投与後は30分間隔で 2 時間体位変換を行い, 4 時間後 に安静解除する。

2. 陰圧環境：薬荗投与直後より $-50 \mathrm{cmH}_{2} \mathrm{O}$ とし, 翌日から連日 $10 \mathrm{cmH}_{2} \mathrm{O}$ ずつ陰圧を減らしていく。水 封となった 24 時間後にドレーンを抜去する。陰圧下の 薬剤吸引防止を目的として，ドレーン接続管を前胸部 より極力高い位置まで挙上する。

\section{気管支充填術}

1. 充填材（Fig. 2)：気管支充填材は endobronchial Watanabe spigot（Novatec 社製，以下 EWS と略す) に加え, endobronchial Miyazawa valve (Novatec 社製, 以下 EMV と略す）の何れかを使用する。 EWS のサイ ズは $\mathrm{S}, \mathrm{M}, \mathrm{L}$ (各最大径 $5,6,7 \mathrm{~mm}$ ) で, 先端と 末端には把持しやすいよう突起が付いている。我々は 抜去を容易とするため，事前に末端の突起に 4-0プ ロレン糸でループを作成している4)。一方, EMV は末 


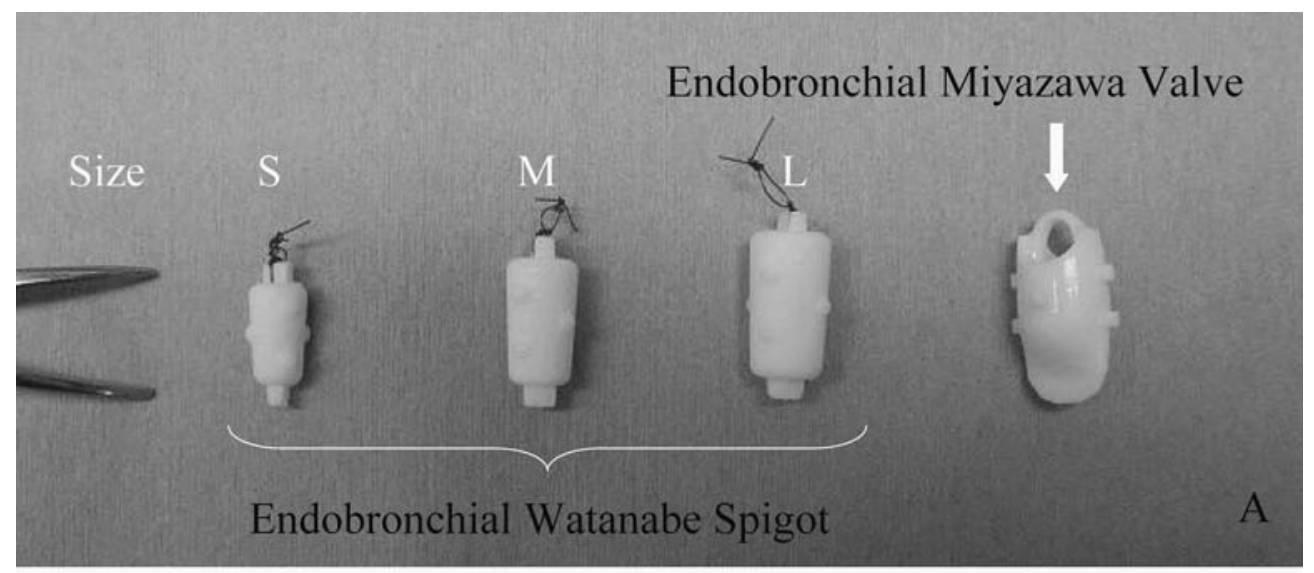

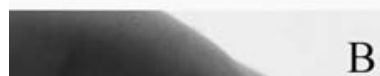

B

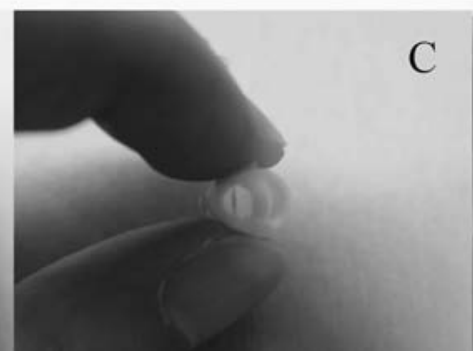

$\mathrm{C}$

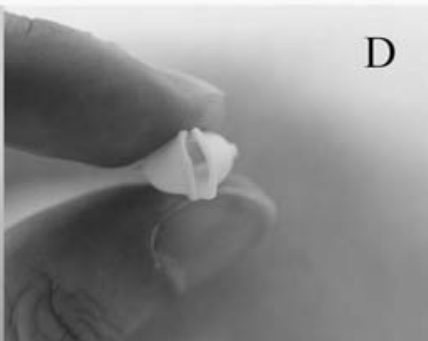

Fig. 2 A: Endobronchial Watanabe spigot (EWS) and endobronchial Miyazawa valve sized S, M, and L, from the left. B: The cut end of the central part of an EWS. C: The peripheral end of an EMV showing the tubular structure. D: The cut end of the central part of an EMV. It can be opened and closed, and clears secretions from the peripheral airway.

端がアヒルのくちばし状となった一方向弁で，気道末 梢の分泌物が排出可能な点が特徵である。サイズは EWS のサイズ L に相当する.

2. 充填方法：術前に胸腔造影や胸部 CT 検查によ り責任肺区域の検索を行い, 当日はプロポフォールに よる鎮静挿管下に気管支鏡を挿入し，渡辺の方法に準 じたバルーン閉塞試験3)を行う。責任気管支の特定後 にシリコン性気管支充填材（主に EMV）を充填する。 充填方法は渡辺原法3) と Push \& Slide 法4,5) を適宜併 用する。 EMVは気管支鏡下に鉗子でEMV 先端のス卜 ラップを把持して区域気管支に留置する。

3. 気管支充填術後の治療: 気管支充填術同日中に 胸膜癒着療法を胸膜癒着療法群と同様に行う。気管支 充填術にて気漏が停止しなくとも, 術前に比較して気 漏が減少し肺の再膨張が得られた場合は有効と判断し 癒着療法を開始する。気漏程度が全く変化ない場合で も, 処置後数時間から半日で減少することが多く, 翌 日には癒着療法を行う。

4. 気管支充填材の抜去：気胸が治癒した場合は, 充填術後 1 力月を目安に抜去する.

\section{結 果}

男42例, 女 3 例で, 平均年齢は72.7歳（52〜88歳） であった。初発症例は42例, 再発症例は 5 例で, この うち両側異時性発症症例が 2 例あった。呼吸器関連基 礎疾患の主な内訳（重複有り）は, 肺気腫・肺囊胞が 28例，間質性肺炎 5 例，対側低機能肺（結核後遺症） 6 例, 患側癒着肺が 7 例, 塵肺 2 例, 多発肺転移症例 が 1 例で, 呼吸器以外の基礎疾患による周術期管理困 難症例が 4 例であった（Table 1).

症例はドレナージ単独群が16例 (17側), 胸膜癒着療 法群が13例 (14側), 気管支充填術併用群が16例 (16側) であった，胸膜癒着療法群の 1 例と他疾患による在院 死 3 例を除いて，41例（43側）が初回に選択した治療 で気漏が停止し退院した。初回に胸膜癒着療法を選択 し気漏が停止しなかった 1 例は，気管支充填術併用療 法に移行し治癒した。平均入院期間 (死亡症例を除く) は各群それぞれ8.4日，23.5日，25.5日であった (Table 2).

再発は現在までの観察期間 (23〜81カ月)にドレナー 
Table 1 Patient Characteristics

\begin{tabular}{llr}
\hline Number of patients & & 45 \\
\hline Median age & Male & 72.7 \\
\hline Gender & Female & 42 \\
& 3 \\
\hline History of pneumothorax & First occurrence & 42 \\
& Recurrence & 5 \\
\hline Bilateral heterochronic development & 2 \\
\hline Underlying disease & Pulmonary emphysema & 28 \\
& Interstitial pneumonia & 5 \\
& Contralateral poor lung function & 6 \\
& Severe adhesion in lung on affected side & 7 \\
& Pneumoconiosis & 2 \\
& Multiple lung metastases & 1 \\
& Difficulty in perioperative control due to diseases & 4 \\
& other than respiratory disease & \\
\hline
\end{tabular}

Table 2 Treatment and Results

Tube thoracostomy group Pleurodesis group Combined bronchial occlusion group

\begin{tabular}{cccc}
\hline $\begin{array}{c}\text { No. of cases } \\
\text { (No. of sides) }\end{array}$ & $\begin{array}{c}16 \\
(17)\end{array}$ & $\begin{array}{c}13 \\
(14)\end{array}$ & 16 \\
\hline $\begin{array}{c}\text { Failure following } \\
\text { initial treatment }\end{array}$ & $2\left(\right.$ death $\left.^{\mathrm{II}}\right)$ & 1 & 1 (death $\left.^{\mathrm{II}}\right)$ \\
\hline $\begin{array}{c}\text { Mean period of hospitalization } \\
\text { (excluding hospital death) }\end{array}$ & 8.4 days & 23.5 days & 25.5 days \\
\hline Recurrent cases & 3 & $2^{*}$ & 0 \\
\hline
\end{tabular}

II No death related to treatment among fatal cases.

* Relapse was confirmed only in cases with the administration of minocycline hydrochloride. No relapse was observed in cases with concomitantly administrated OK-432.

ジ単独群 3 例, 胸膜癒着療法群 2 例で認め, 気管支充 填術併用群は一例も認めていない.

ドレーン単独群で再発した 3 例は, 再度アルゴリズ ムに則って治療方針を決定した。1例は胸膜癒着療法 で，2 例は気管支充填術併用療法にて治癒退院し，そ の後再発はない.

胸膜癒着療法群で再発した 2 例は，ともに全身状態 を考慮してミノサイクリンのみを投与した症例であっ た。再発時はいずれも胸膜癒着療法の適応となったた め, 十分なインフォームドコンセントの後 OK-432を 併用した癒着療法を施行し治癒した。 OK-432併用後 に再発は認めていない.

治療に伴う有害事象としては胸膜癒着療法に伴う一 般的な副作用（発熱，疼痛，倦㤐感）, 気管支充填術後
の一時的な呼吸困難の増悪以外には, 特筆すべき合併 症を認めなかった。在院死亡原因は心肺停止による低 酸素脳症, 気胸治瘉18日後の衰弱, 気胸発症前より認 める対側肺炎であった。前 2 者はドレナージ単独群, 後者は気管支充填術併用群で，いずれも治療関連死亡 ではなかった。

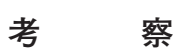

難治性気胸の保存的治療法は胸膜癒着療法, 気管支 充填術に加え, 近年は局所麻酔下胸腔鏡手術の有用性 が報告されている6,7)。局所麻酔下胸腔鏡手術は確か に有用であるが，体位の制限がある症例，癒着が強い 症例，超低呼吸機能症例には限界があり，必ずしも目 的とした治療が行えない場合がある6,7). 
当院では渡辺が開発し有用性を報告した EWSによ る気管支充填術3) に着目し，難治性気胸のみならず， 術後肺瘦, 有瘻性膿胸, 重症肺気腫に対する肺容量減 少術の代用法にも応用してきた ${ }^{3-5)}$. 有用性を再確認 する一方で，気管支充填術のみでは治癒せず胸膜癒着 療法を併用する症例や，EWS を充填した気管支末梢 に気道分泌物が貯留し閉塞性肺炎を起こす症例も経験 した。そこで固形シリコンでバルブ機構を有する EMVを開発するに至った。 EMVは現在も開発途上に あり，今回使用した間に多少形状は変化しているが， 基本的なコンセプトは変わらない.

気管支充填材の改良と気管支充填単独療法による気 胸治療で再発した経験4) を踏まえ, 今回我々は胸膜癒 着療法を中心とした難治性気胸に対する治療アルゴリ ズムを作成した。肺再膨張と気漏の停止が胸膜癒着療 法の成功か否かを左右する ${ }^{2)}$ 点を考慮し, これらの弱 点を克服するべく $50 \mathrm{cmH}_{2} \mathrm{O}$ 陰圧下に行う胸膜癒着療 法と気管支充填術を気漏程度に基づき選択する方法と した。これにより初回治療で確実かつ早期の気漏停止 が可能となった，特に以前は手術を施行していた難治 性気胸症例においても, 気管支充填術と胸膜癒着療法 の併用により, 確実な気漏停止と再発率 $0 \%$ を可能と した。

気漏判定を24時間後に行う理由は，全身状態不良な 症例が多いために体位によって出現・変化する気漏を 見誤る可能性があるためである，治療選択に大きく関 わるだけに性急な判定はせず，十分観察すべきである。

高い陰圧は瘦孔を強固にする, 臓側胸膜に障害をお よぼす, 再膨張に寄与しない, ドレーン本数を増やす ことで再膨張が得られるとの考えもある. 当院でも過 去のSevere 症例 (自然気胸, 外傷性気胸, 術後肺瘦な ど）にドレーンを 3 本挿入し再膨張を試みたが効果が 得られず，結局はより高い㓌圧をかけることで再膨張 を得た症例を経験している。また50 $\mathrm{cmH}_{2} \mathrm{O}$ という陰 圧環境は一時的で, 自覚症状に応じて陰圧を減少する 節度を持って運用しており, 合併症は一例もなくすべ て治癒に至っている。一方, 術後肺瘻には水封管理が 望ましいとの報告があるが8,9), 明らかな肺容量の減 少による術後肺瘦と気胸では病態が異なるため水封が 望ましいと説明する理由にはならない. 胸膜癒着療法 を成功させるには瘦孔部位を強制的に胸壁に接着させ ることが必要である。 $50 \mathrm{cmH}_{2} \mathrm{O}$ 陰圧下に癒着療法を
行ったからこそ, 気漏が顕著な症例でも効果が得られ 再発も少なかったと考元らる。ミノサイクリンと OK-432の併用によりドレーンが閉塞する恐れや，不 十分なドレナージで初回治療が不成功となった経験か らも，陰圧は必要な条件と考えている。

気管支充填術併用群のうち, 気管支充填術単独で気 漏が停止する症例は一部で, 停止後に再び気漏を認め る症例もあった。実際，気管支閉塞試験で責任気管支 が同定される症例は少なく, 胸腔造影の所見から大ま かな責任領域の気管支に対してEWSまたはEMVを留 置した，留置後の気漏停止例は 1 側のみで，13側で気 漏が減少し，4側は変化しなかった。気漏程度に変化 がなかった症例でも充填後数時間から半日後に気漏が 減少することが多く，全例翌日には癒着療法を開始し た。

胸膜癒着療法の薬剤は, 作用機序が異なる点と併用 の有用性が報告されていること10) からミノサイクリン と OK-432を使用した。副作用による全身状態の悪化 を恐れて OK-432を投与しなかった症例が 2 例あり，

いずれも再発した，OK-432を併用した胸膜癒着療法 の後は再発を認めていないことから，OK-432は併用 するべき薬剤と考えられた。ただし間質性肺炎を有す る場合は，再発のリスクと間質性肺炎急性増悪のリス ク11をを踏まえた上で十分説明し同意を得なければなら ない.

主な治療合併症に胸膜癒着療法の副作用と気管支充 填区域分の呼吸機能低下があげられる。特に気管支充 填術併用群では，気胸治癒後に呼吸困難を訴える症例 があった。しかし症状は一時的で，充填材抜去まで気 管支拡張剂や在宅酸素療法の導入により十分対処可能 であった，閉塞性肺炎は一例もなく，主に EMVを充 填したことやマクロライド系抗生物質の低容量内服の ためと考えられた。

今回気胸治癒は速やかであったものの，多くの症例 でドレーン抜去から退院までに時間を要した。発症時 の症状が強く本人や家族が不安で退院を渋ったことや， 高齢故に家族が引き取るまでに時間がかかったことが 原因であった，患者背景や環境によっては退院期間の 短縮は図れるであろう。

\section{結 論}

難治性気胸に対する本アルゴリズムは治療法選択に 
有用であった。 なかでも50 $\mathrm{cmH}_{2} \mathrm{O}$ 陰圧下に行う胸膜 癒着療法と気管支充填術を用いた治療は, 速やかな気 漏停止と肺再膨張を促し再発防止に有効であった。本 論文の内容は第25回日本呼吸器外科学会学術集会シン ポジウムで発表した.

\section{文献}

1. 大㴊俊朗, 植田充宏, 河下太志, 和田洋巳. 吸収性メッ シュの肺表面癒着による難治性気胸に対する胸膜全面癒 着術一LAM の 1 例。日呼外会誌 2005; 19: 628-31.

2. 阪口全宏, 中村憲二, 高橋 修, 須崎剛行. 繰り返し気 胸を発症した肺リンパ管脈管筋腫症の 1 例一肺移植対象 疾患での胸膜癒着術に関する考察一. 日呼外会誌 2006; 20: $781-5$.

3. 渡辺洋一. 気管支充填術. 気管支学 2005; 27: 475-8.

4. 宮澤秀樹, 新納英樹, 能登啓文, 藤坂志帆, 谷口浩和, 泉 三郎．EWS を用いた気管支充填術の検討一新しいEWS の充填法 (Push \& Slide 法) と Bronchial Lung Volume Reduction への適応一，気管支学 2003; 25: 695-703.

5. 宮澤秀樹。難治性気胸に対する EWS を用いた気管支充
填術の検討一新しい EWS の充填法 (Push \& Slide 法) 一. 日気囊疾会誌 2004; 6: 21-7.

6. 石井芳樹。局所麻醉下胸腔鏡でどこまでできるか. 医学 のあゆみ 2003; 206: 957-60.

7. 渡辺健寛, 古泉貴久, 小池輝元, 広野達彦. 難治性気胸 に対する局所麻酔下胸腔鏡手術の成績. 日呼外会誌 2007; 21: 118-22.

8. Marshall MB, Deeb ME, Bleier JI, et al. Suction vs Water Seal After Pulmonary Resection: a randomized prospective study. Chest 2002; 121: 831-5.

9. Okamoto J, Okamoto T, Fukuyama Y, et al. The Use of a Water Seal to Manage Air Leaks after a Pulmonary Lobectomy: A Retrospective Study. Ann Thorac Cardiovasc Surg 2006; 12: 242-4.

10. 田中明彦, 佐藤 諦。悪性胸水の貯留防止に有効であっ たミノサイクリン，OK-432 併用胸腔内注入療法。日呼 吸会誌 1999; 37: 531-7.

11. 草野英美子, 本間 栄, 大津喜子, 他. タルク末注入と 胸腔鏡下肺㾞閉鎖術が奏功した特発性肺線維症合併難治 性気胸の 1 例。日呼吸会誌 2005; 43: 117-21.

\title{
Therapeutic strategy for intractable pneumothorax - Combined use of bronchial occlusion therapy and high-negative pressure pleurodesis-
}

\author{
Takahiro Honma, Hideki Shinno, Hideki Miyazawa, Hirofumi Noto
}

Department of Respiratory Surgery, Toyama Prefectural Central Hospital, Toyama, Japan

The results of conservative medical management for intractable pneumothorax were analyzed in 45 patients hospitalized in our department from 2002 to 2006. The therapeutic strategy was determined by taking into consideration the degree of deaeration and re-inflation of the lung after a tube thoracostomy procedure comprising a tube thoracostomy, pleurodesis, or combined bronchial occlusion therapy. For bronchial occlusion therapy, silicon filling materials were used. For pleurodesis, adhesion was attempted under $50 \mathrm{cmH}_{2} 0$ negative pressure. In all cases, except for 1 in the pleurodesis group and 3 cases of hospital death not related to treatment, the subjects were discharged from the hospital with deaeration stopped by the therapy selected in the initial treatment. We consider that our therapeutic strategy for intractable pneumothorax is effective, as well as very safe and reliable, as there were few cases of relapse. 